\title{
Theory Building of Quattro Bottom Line Approach for Sustainable Reverse Logistics from Government Perspective: the Indonesia Evidence
}

\author{
Hesti Maheswari*, Gatot Yudoko, Akbar Adhiutama \\ School of Business and Management. Institut Teknologi Bandung, Bandung 40132, Indonesia
}

\begin{tabular}{l} 
A R T I C L E I N F O \\
\hline Article history: \\
Received: 11 June, 2018 \\
Accepted: 7 July, 2018 \\
Online: 23 July, 2018 \\
\hline Keywords: \\
Sustainable reverse logistic \\
Quattro bottom line \\
Government perspectives
\end{tabular}

\section{Introduction}

This paper is an extension of work originally presented in Industrial Engineering and Engineering Management Conference, IEEM 2017 [1] that wants to prove the need for government role in building sustainable reverse logistics (SRL) theory by using quattro bottom line approach. This study departs from the researcher's belief that the success of handling e-waste depends on an active role of government. At least there are three roles of government in supporting reverse logistics (RL) implementation. First, as a policy maker, government makes regulations and policies in preserving the environment [2], second, as a regulator, government arranges RL implementation, and third, as a facilitator, government provide facilities to conduct RL activities. Actually, electronic and electrical products are considered as luxurious and unaffordable things for middle-lower income country. However, due to the increasing of the Indonesian income per capita that almost reached 4 million per month, communities consumptive behavior, and the growth of industrial capability reflected in gross domestic products (GDP) of Indonesia more than

*Hesti Maheswari, Jl. Rudal Raya No. 3A Joglo West Jakarta 11640 - Indonesia, +6282123596058 email: hesti.maheswari@sbm-itb.ac.id

www.astesj.com

https://dx.doi.org/10.25046/aj030410
$5 \%$, the third highest in the Group of Twenty (G20) after China and India [3], lead the community to replace electronic products faster than it should be. Generally, the Indonesian people persist on using their mobile phone (MP) are not more than three years [4], which causes these products contribute the largest amount of e-waste compared with other electronic devices [5].

Along with the highest rate of electronic products replacement, increase also the amount of e-waste, while, only a few of them are recycled. Nokia mobile phone survey noted that only $9 \%$ of ewaste mobile phones are recycled in India and China, and only $1 \%$ in Nigeria and Indonesia [6]. The biggest role in recycling activities comes from informal businesses [7] that pay more attention only to target profit achievement and do not care with the environment. This is the reason for the great role of government to control recycling programs. Through government policies and regulation, not only balancing profit and reputation achievement, but also protecting the environment and social harmony. The rules and regulations should be designed properly to arrange how to take benefit from recycling process without disturbing other interest.

As mentioned before, the success of a a country in conducting recycling program depends on the role of government to encourage 
and regulate it [2]. Providing a high technology recycling needs enormous budget allocation. In developed countries, the amount of e-waste is regarded as a resource for other business. They convert e-waste into energy or other valuable products. Furthermore, the government early anticipate the number of product produced in forward chain. They think early to create a handling mechanism by making RL activity as an obligation for everyone, either businesses or societies. Unlike in developed countries, regulations in emerging countries are always left behind. The rules or acts will be created after government feels there is a crucial problem. Even though RL activity is conducted, they are often ignoring the environmental friendly way. The main characteristics of emerging countries RL model as compared to international models [7] is depicted in Table 1.

Table 1: Comparison of RL models in developed and emerging countries

\begin{tabular}{lccccc}
\hline & \multicolumn{2}{c}{ Developed Countries } & \multicolumn{2}{c}{ Emerging Countries } \\
\cline { 2 - 6 } & Switzerland & Sweden & China & India & Brazil \\
\hline Government & Active & Participative & Inactive & Inactive & Active \\
Industry & Total Mgt. & Transportation & Ships & & Total Mgt. \\
Consumer & $\begin{array}{c}\text { Pays ARF } \\
\text { returns }\end{array}$ & Return & & & \\
& & & & & $\begin{array}{c}\text { Pays } \\
\text { embedded } \\
\text { fee and } \\
\text { returns }\end{array}$ \\
Informal S & & & Excluded & $\begin{array}{c}\text { Pre- } \\
\text { processing }\end{array}$ & $\begin{array}{c}\text { No } \\
\text { training }\end{array}$ \\
\hline
\end{tabular}

There is no opportunity for informal sector in developed countries to get profit through RL activities. The government strictly prohibits informal sector to recycle used electronic products because they are often ignoring the environmental sustainability. While, in many emerging countries, the informal sector plays a major role in recycling e-waste activities, even becoming home industry but illegal.

According to my preliminary research, in fact, there are many Indonesian people want to participate in recycling MP program by sending it to collecting point [4]. Unfortunately, most of them said that they do not know where to bring it for recycling since they are hard to find the drop box facility [4]. Some of them are reluctant to send their used MP, and prefer to keep it at home due to unreasonable of reimbursement. They are also hard to find someone else who really want to use it. Others explained that it is very difficult to sell the obsolesce or out of date electronic product to secondary market [4]. These phenomena show that recycling mechanism in many emerging countries that actually can be used for handling e-waste problem, are not built yet.

From literature reviews, we found that since 1990s until now, people all over the world have felt the need for RL, although their aims are not purely to protect the environment. They are focus on profit or embarrassment if their activities are littering surrounding $[8,9]$. Therefore, in that era, many researchers studied about how to improve firms' performance in reverse chain. Evolution of RL theories refer to original constructs built by some previous studies such as reverse logistics network that explored the types of RL activities [10] and motivation [11], organizational commitment [11-14], and RL performance [15]. The author is hard to find a research that explores the role of government in encouraging communities to participate actively in RL program, how the government regulates RL mechanism, how the government assigns businesses to conduct RL activities, and how the government oblige societies to participate. Therefore, today it is relevant to sift the research idea to focus on government role in preserving the environment through RL program that consider not only profit, planet, and people elements, but also consider reputation factor. Due to low of public awareness in emerging countries even they pollute the environment although they conduct RL activities, therefore, the researcher believes that RL concept is not enough and this study proposes to use sustainable reverse logistics (SRL) terminology. Moreover, the researcher believes that SRL concept must be explored and created from government policies, regulations, perspectives and expectations. So, by investigating the linkage and the gaps among theories, finding the governments expectation by interviewing them, and generating a suitable pattern of the program, this study wants to build a SRL theory based on quattro bottom line (QBL) approach, include reputation terminology as a new idea and very relevant with current situations but has not emerged in the research publication.

The rest of this paper is organized as follows. The second section explores literatures related to sustainable reverse logistics, government rules, policies, and performance. The third section discusses the research method, data collection process and highlight the variables for building a theory. The fourth section explains the main finding. Finally, the fifth section summarizes the research and suggests further research.

\section{Literature Review on Sustainable Reverse logistics}

Exploration of sustainable reverse logistics concepts are directed to prove that the main purpose of conducting SRL programs are protecting the environment. Furthermore, the success of this program particularly in emerging countries, depends on the role of government to encourage other stakeholders. Therefore, the actions that support RL implementation, governments' performance, and sustainability concept will be the main themes in this paper. Related to sustainability concepts, this paper uses quattro bottom line approach because the researcher believes that it is not enough without spelling out reputation concepts for research in the context of emerging countries.

\subsection{Sustainable Reverse Logistics Actions}

Reverse logistics is the process of planning, implementing, and controlling the efficient, cost effective flow of used electronic products from the point of consumption to the point of origin for the purpose of recapturing or creating value to prevent environmental pollution [11]. From this definition, it is illustrated that RL activities should be able to protect the environment and one of the ways is adding span of life electronic products especially for MP that has the shortest product life cycle.

There are 8 types of reverse logistics activities [16], namely remanufactured, reconditioned, refurbished, re-process, repair, recycle, reuse, and disassembly. However, only 5 types are commonly done in emerging countries, i.e.: refurbished, repair, recycle, reuse, and disassembly [17] and usually many informal businesses are doing these activities. On the contrary, only a few manufacturers take a part in RL program and only a little role of government in regulating mechanism of RL implementation. Therefore, this research seeks to find actions that support SRL theory building, either from literatures or practices. 
This research divides type of reverse logistics actions based on who is recommended by government to perform the activity, whether businesses (manufacturer or intermediary business), consumers, or governments itself. Knowledge, willingness, and awareness of all stakeholders to the environmental sustainability are believed to be a strong foundation to commit in supporting SRL program.

\subsection{Sustainability}

In manufacturing industries, after the achievement of quality, differentiation, and cost leadership as the leverage of their competitive advantage, management has to concern about strategic issue such as the environment. The most integrated performance of supply chain either in forward or reverse network is the business development in line with sustainability. Sustainability is a set of skill and concepts that allow all parties to obtain competitive returns without sacrificing people and environment interest [8]. Aptly joining the definition of reverse logistics and sustainability brings about sustainable reverse logistics (SRL). The industry must control not only financial achievement, but also consider its impact on economic as a whole, environmental protection, and social responsibility which conform to the triple bottom line (3BL): economic value, environmental and social responsibility (Figure 1) [18]. Others stated that the most important reasons in implementing RL activities are economic (decreasing the use of raw materials, reduction of disposal cost, creation of added value for and-of-use products, and demonstrating of environmentally responsible behavior), legal (implementing extended producer responsibility as follow the government rule), and social (preventing environmental pollution from carbon emission and ewaste generation) $[19,20]$. The worries on corporate image, government responsibility, and communities' awareness are sometimes become the reason of all stakeholders to conduct RL programs.

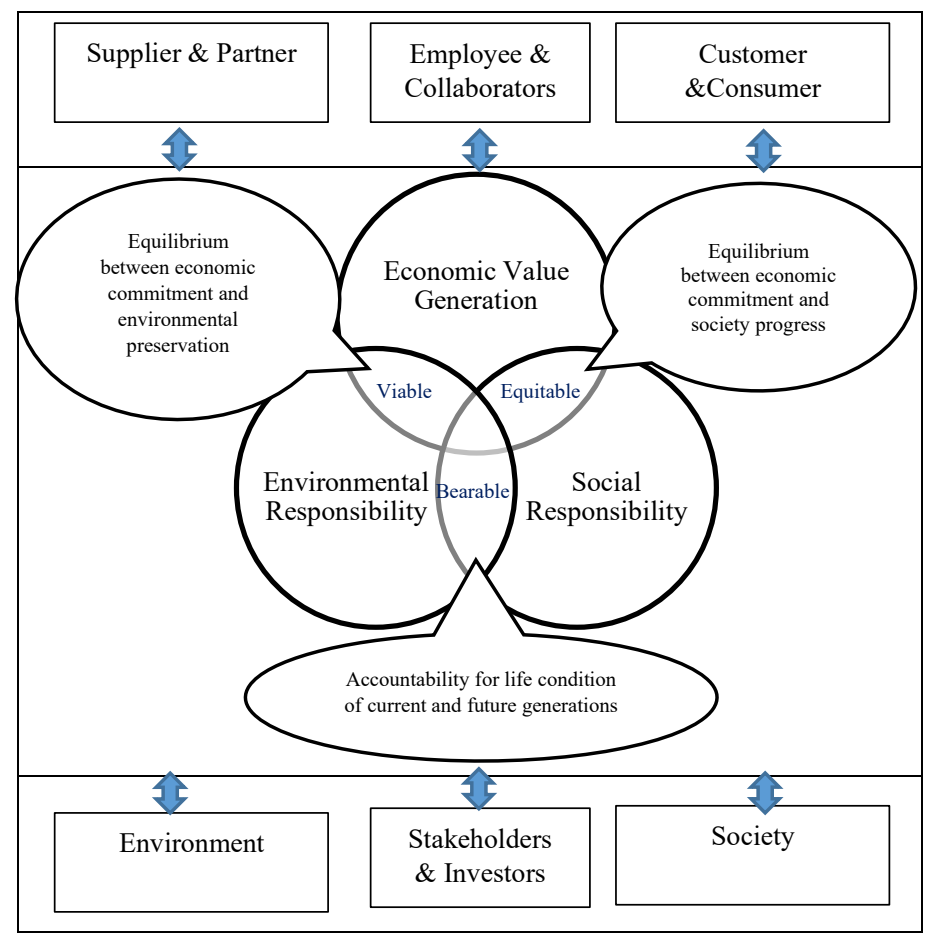

Figure 1: The triple bottom line [Pedroso in [16]
Figure 1 explains about interactions among social, environmental and economic spheres result in deeper and more complete aspects of sustainability. The relation between economic and social prioritizes job creation and income to improve living standards, economic welfare and growth that favor social aspects, besides increase level of education and professional development. Intersection between the economic and environmental spheres stresses to create benefit from various activities but still pay attention to environmental sustainability such as designing ecofriendly products and developing methods for electronic product volume reduction [21]. Further, interaction between social and environmental spheres indicates that communities have to use electronic products properly reflected in accountability for life condition of current and future generations. Finally, intersection of the three spheres represents sustainability in a broader sense. These issues will be the central topic in this study because most parties are often fail to maintain the balance among the profit target achievement, planet conservation, and social harmony.

\subsection{Reputation}

Reputation in an organizational context, is generally related to two dimensions, first, how stakeholders perceive the quality of specific attributes, and second, the degree to which an organization or company is recognized collectively [22]. From a business perspective, reputation has been defined as the combination of a company's public prominence, its public esteem, and the qualities or attributes associated [22, 23]. In other word, a company or organization is recognized on a large-scale and salient in the minds of stakeholders. From government perspective, reputation concepts are defined as responsibility of a country from various problems especially that giving negative impacts and disturbing to other countries. While, for the communities, reputation is related to their willingness to actively involved in preserving the environment.

There are six dimensions of reputation [24], namely:

- Emotional appeal (likeability, respectfulness, and trustworthiness);

- Physical appeal (attractiveness of an infrastructure);

- Financial appeal (favorable environment for stakeholders);

- Leadership appeal (charismatic leadership and a clear vision);

- Cultural appeal (socio-cultural diversity, history, entertainment);

- Social appeal (the perceived responsibility as a member of the global community and the manifest support for good causes)

\subsection{Government Policy, Regulations, and Performance}

Government has a range of policy instruments that can be divided into six broad categories to reduce the environmental impact of freight logistics [25], namely: taxation; financial incentives; tariff regulation; liberalization and privatization of freight markets; infrastructure and land using planning; as well as advice and exhortation. Government as a regulator can run ewaste management system through realizing extended producer responsibility (EPR) implementation; corporate social responsibility (CSR) mechanism, energy and row material control, take back program application, environmental-friendly product utilization, e-waste budget allocation, deposit fund requirement, international end-of-life standard, 4Rs program application [21] 
and skill accreditation [26, 27]. Government as a facilitator should provide drop box that easy to find by communities, storage point, and landfill areas. Indonesia Waste Forum (IWF) requires five aspects which must be considered to solve waste problem in emerging countries they are law and national policy, national institution for integrated implementation, financial investment, community involvement, and technology creation [28].

\section{Research Method}

\subsection{Method}

The perfect research design is built to ensure all research questions will be answered [29]. This research uses quantitative and qualitative approaches and the design is divided into five steps that depicted in Figure 2.

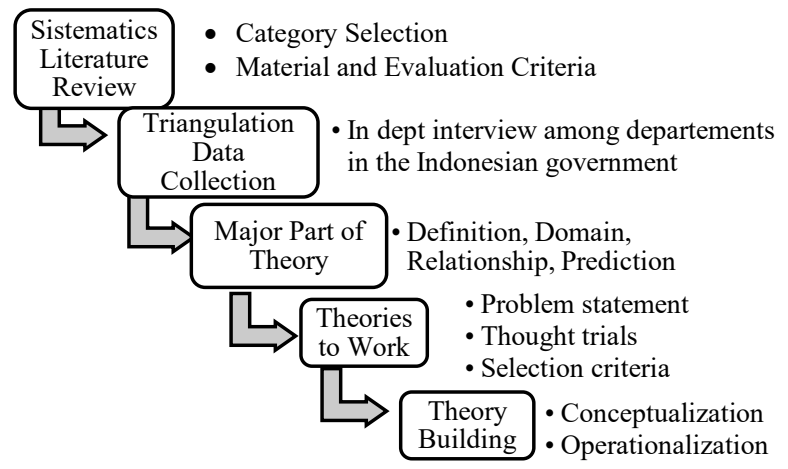

Figure 2: The research flow

First, in quantitative approach, this research chooses systematic literature review [30], that comprised of two steps i.e.: category selection and material evaluation. In the category selection step, firstly this study defines and refines a topic, then designs a search and locate research report. This study uses two main topics namely: reverse logistics and sustainability. This study explored many researches without limiting the year of their publication. After that, they are reviewed and classified by differing their characteristics and distinguished and then recorded in a prepared spreadsheet to be analyzed holistically. The different characteristics in reverse logistic concept are its activities and network while the sustainability concept refer to the fulfillment of Quattro bottom line approach. Secondly this study determines how to evaluate the material by using validity test, crosschecked for ensuring the enrichment of study such as Scopus indexed, journal accredited, and the research quality that answering its research question.

Because this research wants to build SRL theory from government perspective and expectation, therefore in the end of this section will be served the measurement of government performance that conduct RL activities. For evaluating performance of government, this research chooses three types of evaluations [31], namely: criterion-focused evaluation (by what criteria shall the SRL program be evaluated?), impact focus (what are the direct and indirect SRL program impacts, not only on participants, but also on larger systems and the community), and implementation focus (to what extent was the program implemented as designed? What issue surfaced during implementation that need attention in the future?)
Second, to complete the constructs, this research applies a qualitative method by using triangulation data collection (i.e. indepth interview between departments in the Indonesian government) for six months from January 2017 to April 2018. Third, this research adopts that theory comprises of four major parts, i.e.: definitions, domain, relationships, and predictions [32]. Definitions translate the concepts, constructs, or variables used in the theory by using "what?" and "who?" questions. Domains refers to where the theory applies with answer the questions of "where?" and "when?". Relationships shows the nature of causality among those concepts, constructs, or variables selected by answering "why?" and "how?" questions. Predictions reflects whether the theory will give impact in the field by applying the questions of "could, should, and would?" Fourth, Weick's theorizing as disciplined imagination provide three tools for theorist to work with in crafting theories, i.e.: problem statement, thought trials, and selection criteria [29]. and Fifth, the general method of theory building in applied discipline comprises of five nonlinear phases: conceptualization, operationalization, confirmation, application and refinement [29]. This research is only use the first two phases, i.e.: conceptualize and operationalize. The purpose of conceptualization phase is to develop a sound conceptual framework that provides an initial understanding and explanation of the nature of problem and phenomena. While, the purpose of operationalization phase is to bridge the concept and practice. Although, the operationalization of a theory needs to be tested or confirmed, in this paper, the confirmation phase is not conducted because of the interview results refer to government policies and regulations. In turn, the theory is likely to result in better outcomes and appropriate to be implemented.

\subsection{Samples}

Since lack of community awareness in emerging countries to reduce e-waste and preserve the environment, so the theory formation must be generated from government perspectives.

Table 2: Government and selected respondents

\begin{tabular}{|c|c|}
\hline Nat & Respondents \\
\hline $\begin{array}{l}\text { - Ministry of Environment } \\
\text { and Forestry (MEF) }\end{array}$ & $\begin{array}{l}\text { - The head of sub directorate of e-waste and } \\
\text { recycle } \\
\text { - Directorate General of Waste, E-Waste, } \\
\text { Hazardous and Toxic Material }\end{array}$ \\
\hline - Ministry of Industry & $\begin{array}{l}\text { - Directorate Industry of Electronic and } \\
\text { Telematic } \\
\text { - Directorate Small Medium Industry of Metal, } \\
\text { Machine, Electronic and Conveyance }\end{array}$ \\
\hline - Ministry of Trade (MT) & $\begin{array}{l}\text { - The Head Agency of Assessment and } \\
\text { Development of Trade Policies }\end{array}$ \\
\hline $\begin{array}{l}\text { - Ministry of National } \\
\text { Development Planning } \\
\text { (MNDP) }\end{array}$ & - Directorate of Environment \\
\hline $\begin{array}{l}\text { - Ministry of Cooperation, } \\
\text { Micro and Small } \\
\text { Medium Enterprise } \\
\text { (MCSMEs) }\end{array}$ & $\begin{array}{l}\text { - Secretary for Deputy Minister of Business } \\
\text { Restructuring }\end{array}$ \\
\hline $\begin{array}{l}\text { - Environment and } \\
\text { Hygiene Office (EHO) }\end{array}$ & $\begin{array}{l}\text { - The Head of Environment and Hygiene Office } \\
\text { - The Head of Hygiene Management } \\
\text { - The Head Control of Environmental Impact }\end{array}$ \\
\hline 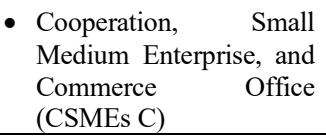 & $\begin{array}{l}\text { - The Head of Cooperation, Small Medium } \\
\text { Enterprise, and Commerce Office }\end{array}$ \\
\hline
\end{tabular}


By interviewing the government officials, this research wants to catch the various constructs considered for implementing SRL activities. This research chooses five ministries and two government agencies that are predicted influencing the successful of SRL implementation. Not all of divisions in those ministries made as respondent. Table 2 is detailing who the respondents are.

\section{Result and Discussion}

This section consists of five parts following the research flows. The first part is exploring the existing theory include the evolution of RL and further about SRL theory. The second part is recording the government policies and regulation plus roles and responsibilities from in dept interview. Then, the third part is elaborating the definition, domain, relationships, and prediction of SRL theory, the fourth part is selecting the SRL criteria through problem statement and thought trials, and the last part is pattern matching of the concept with the practices to create the sound of sustainable reverse logistics theory.

\subsection{Evolution of Reverse Logistics and Sustainable Reverse Logistics Theory}

Firstly, some businesses conducted reverse logistics activities for getting profit from used electronic product $[4,11,12,15,18$, 33-35]. Actually, the idea of returning electronic product emerged around 1940s to 1970s. They did not recycle or conduct other form of RL activities. Usually they resell used electronic products to other. If those products cannot be sold, they kept it at home, sometimes become a children's toy, or throw them in the bin mixed with household waste. However, in the recent years, they began aware with environmental condition which resulted by more and more used electronic product that make the narrowness of dumping grounds. Actually, RL activities are closely related to sustainability concepts with the three perspectives (triple bottom line, 3BL), namely: profit, planet, and people [8]; economic value, environmental and social responsibility based on Pedroso and Swicker [18]. Types of reverse logistics activities such as remanufactured, reconditioned, refurbished, re-process, repair, recycle, reuse, disposal, and disassembly $[10,15,18]$ are manifestation of sustainability movement. However, for many emerging countries, the use of 3BL concept is not enough. RL managed efficiently and effectively has the potential to gain economic value and enhance the positive image of the firm in the consumers' perception and the distribution chain [33]. RL managed effectively help to improve after-sales service as fast to respond to complaints and solve problems which is able to provide certainty that the returns enhance the positive image of firms [20]. The firms deliberately doing RL activity to get attention from societies because mitigating environmental, health, and safety impacts can enhance a firm' reputation [8]. For the government, they worry if their e-waste pollutes neighboring countries and they get negative image from them. Today, societies also worry about getting social sanction, if their behavior is not responsible or lack awareness to the environment. Social perspective to assess reverse logistics performance is also considered as part of reputation concept with some indicators such as market reputation of the enterprise if they produce unqualified product and do not have a technology for handling their own e-waste [15]. This matter makes the researcher believe that not only businesses but also government and communities expecting a good reputation in realizing it [4].
Discussion of sustainability are driven by the basic concept that reverse logistics' performance should be measured not only by profits and reputation, but also by the impact of activities on environmental and social systems. Therefore, there is a tight correlation between reverse logistics and sustainability. Unfortunately, in many emerging countries, in fact, RL activities are often not managed and controlled properly by government. They are still concern to produce a new qualified electronic product in forward chain, provide technology to develop features, promote, and sale it in the market as much as possible. They forget to early anticipate e-waste problem. Meanwhile, the informal sector from community more quickly respond by looking at it as a business opportunity. After that, a new problem emerges in almost all emerging countries as they move without government permission and ignore health and safety work. They only think about how to fulfil their needs or how to earn a lot of money. These phenomena make the author convince to use sustainable reverse logistics terminology if we want to study about all activity in reverse chain.

\subsection{Government Policies and Regulations plus Roles and Responsibilities}

Many emerging countries have no rules, act, or legislation completely related to SRL implementation. Some rules bellow will be used as a foundation of building SRL theory. For example, Indonesia just made a rule about the obligation of businesses to manage their used product, if it is hard to decompose by natural process in Act No. 18 of 2008, article 15.

The last government regulation related to face e waste problem is No 101 of 2014, article 1, verse 11 - 31 that concern with managing e-waste. Indonesian government also prohibit businesses to import used electronic product, e-waste, hazardous, and toxic material as shown on Decision of The Ministry of Trade No. 229/MPP/Kep/7/97 and Basel Convention of 1989. Polluter pay principle is also set in Act No. 32 of 2009 article 2 verse (i) and Government Regulation No.18 of 1999 article 9 verse (1, 4, 5). For reducing e-waste, government assesses and control the quality of product through national standard of Indonesia (SNI) that enforced mandatory for electronic product in regulation of The Ministry of Industry No. 36/M-IND/PER/9/2017. Indonesian government form adjusted assessment institution in order to SNI enforcement.

Ministry of Industry has machines restructuration and/or other equipment program for small and medium industries in rule of Ministry of Industry No. 20/M-IND/PER/3/3/2016to help them improve the quality of products. So, the procurement of machine should not be a problem anymore for converting e-waste to other valuable product. Government also encourage all businesses to reach green industry certification as arranged in rule of The Ministry of Industry No. 18/M-IND/PER/3/2016. For increasing the number new of entrepreneurs, Indonesian government makes new business invention program and train them until it becomes an established business as shown on Act no 20 of 2008. Government make serious effort to link and match small and medium enterprises with the big industry to learn the technology and improve their skill that arranged in PP No. 17 of 2013. There is no rule, act, and other form of regulation that organize how to conduct SRL activities, who should be responsible, what the role 
of each actor is, and what kind of punishment if they are breaking the rule. As explained in previous section, because of community lack awareness the concepts of SRL must derive from government initiative. Therefore, this author formulates the theory of SRL from the government perspective.

This research explores the roles and responsibilities of national agencies related to SRL implementation by interviewing them. These roles and responsibilities will be a fundamental construct in building SRL theory (Table 3)

Table 3: Government roles and responsibilities

\begin{tabular}{ll}
\hline National Agencies & Roles and Responsibilities \\
\hline - Ministry of Environment & - Define responsibilities for stakeholder \\
and Forestry (MEF) & - Define SRL categories for business \\
& - Establish and manage e-waste collection \\
& channel and systems \\
& - Establish e-waste treatment standard \\
& - Manage licensing system for business \\
& - Monitor and evaluate business \\
& environmental performance
\end{tabular}

\subsection{The Major Part of Sustainable Reverse Logistics Theory for Emerging Countries}

The SRL theory especially for mobile phone industry has not been extensively studied and conceptual models explaining the possible recovery network have not been abundantly created [8]. So, the implementation of RL activities in almost all emerging countries is more damaging the environment because it still does not consider sustainability concepts since there is no theory that fortifies these activities. For gaining the sound theory, four major parts of theory (definition, domain, relationship, and prediction) [32] will be described in table 4-7. This research explains what SRL is, who should play a role, when and where it must be implemented, why it is important, how it is applied, whether it can be implemented, how it should be implemented, and will all parties participate.

Table 4: Definition component

\begin{tabular}{ll}
\hline Questions & Description \\
\hline What? & $\begin{array}{l}\text { Sustainable reverse logistics is designed as an attempt to } \\
\text { guarantee activities in reverse chain in line with the primary } \\
\text { goals such as profit, social harmony, and environmental } \\
\text { preservation. This theory is really needed especially in } \\
\text { emerging countries to fortify community activity in utilizing }\end{array}$ \\
& used electronic products to get profit. \\
Who? & $\begin{array}{l}\text { Governments are the backbone in enforcing sustainable } \\
\text { reverse logistics implementation who formulate the } \\
\text { mechanism includes educating and socializing to }\end{array}$ \\
& $\begin{array}{l}\text { community and also organizing it. Due to implementation of } \\
\text { sustainable reverse logistics theory requires collaboration of } \\
\text { all parties, therefore not only government, but also } \\
\text { manufacturer or producer, intermediary business, and } \\
\text { society should be involved }\end{array}$ \\
\hline
\end{tabular}

Table 5: Domain component

\begin{tabular}{ll}
\hline Questions & Description \\
\hline When? & $\begin{array}{l}\text { Sustainable reverse logistics should be done when production of } \\
\text { electronic products in forward chain takes place and followed by } \\
\text { consumptive behavior, to anticipate e-waste generation }\end{array}$ \\
Where? & $\begin{array}{l}\text { Sustainable reverse logistics is designed for community in } \\
\text { emerging countries especially in a country where the population } \\
\text { has low of the environmental preservation awareness }\end{array}$ \\
\hline Questions & \multicolumn{1}{c}{ Table 6: Relationships component } \\
\hline Why? & $\begin{array}{l}\text { The Indonesian government, through Ministry of Environment } \\
\text { and Forestry, Ministry of Industry, Ministry of Trade, Ministry } \\
\text { of National Development Planning, and Ministry of }\end{array}$ \\
& $\begin{array}{l}\text { Cooperation, Small Medium Enterprise should concern with the } \\
\text { environmental quality degradation due to a lot of e-waste. }\end{array}$ \\
Because of lack community awareness, the sustainable reverse \\
logistics theory must be developed from government side. \\
Government policy and intervention will be the right \\
breakthrough for encouraging all parties aware with \\
environmental sustainability. Finally, this theory is expected \\
become a guidance for all parties who are looking for profit on \\
reverse chain. \\
$\begin{array}{l}\text { The Indonesian government can apply sustainable reverse } \\
\text { logistics theory by arranging its mechanism, making the rules } \\
\text { and regulations, determining the role of each stakeholder, } \\
\text { developing infrastructures or facilities, preparing the community } \\
\text { knowledge, and controlling the implementation continuously. } \\
\text { The expected outputs from this theory building refer to } \\
\text { sustainability achievement through quattro bottom line } \\
\text { approach, encompass business profit either for producers or } \\
\text { intermediary businesses, local and national economic growth, } \\
\text { social welfare, and environmental preservation as well as all } \\
\text { parties' reputation since their effort and participation. }\end{array}$ \\
\hline How?
\end{tabular}

Table 7: Prediction component

\begin{tabular}{ll}
\hline Questions & Description \\
\hline Could? & $\begin{array}{l}\text { The Indonesian Government believes and expects that sustainable } \\
\text { reverse logistics theory could be implemented in emerging } \\
\text { countries for handling e-waste problems. }\end{array}$
\end{tabular}

Should? To implement sustainable reverse logistics theory, the activities should refer to quattro bottom line fulfilment. The balancing among profit target achievement, social value creation, environmental preservation, and reputation acquisition should become a fundamental orientation.

Would? All parties would adhere to government regulation since they receive equal treatment between the fulfilment of rights and the implementation of obligation

\subsection{The Categories Selected for Sustainable Reverse Logistics Theory for Emerging Countries}

The SRL categories combining literatures, field practices, and also government roles, responsibilities, regulation and expectation are summarized in table 8. This research found 53 categories which will be used as the constructs for SRL theory, while the definitions of each categories are provided in the appendix. There are 17 constructs are not found in literature, but regarded very important in building SRL theory for emerging countries. They are standard equipment utilization; training for SMEs in reverse logistics activities; inclusion of product content and duration; fairness in using electronic product; illegal import restriction, Electronic product national standard arrangement; vocational education for human resource preparation; business localization; tax arrangement; restructuration machine program; budget provision; rules alignment; social punishment; control 
mechanism of RL implementation; SMEs-industry link and match; Modernization of SMEs; and social and public facility utilization. We give star mark for the seventeenth constructs to differentiate the both constructs source clearly.

Government recommends 18 actions of SRL for businesses. Three of them are found from interview result, namely encouraging utilization of standard equipment to avoid hazardous and toxic materials from e-waste; giving training to small medium enterprise in e-waste processing and use of e-waste conversion technology, and writing down the product life and product content on the packaging. Although other 15 action are found from literature, however only 2 actions have been conducted in Indonesia, i.e. giving after sales service and providing drop box facilities but with limited number.

Table 8: Sustainable reverse logistics concepts for emerging countries: summary of in depth interview results and literature review

\begin{tabular}{|c|c|c|c|c|c|c|c|c|}
\hline \multirow{2}{*}{ Sustainable Reverse Logistics Categories } & \multicolumn{7}{|c|}{ Actions Recommended by Governments } & \multirow{2}{*}{ Literatures } \\
\hline & MEF & MI & MT & MNDP & MCSMEs & $\mathrm{EHO}$ & CSMEC & \\
\hline \multicolumn{9}{|l|}{ Businesses: } \\
\hline Eco-friendly product design & $\sqrt{ }$ & $\sqrt{ }$ & - & - & - & - & - & {$[20]$} \\
\hline After sales service & $\sqrt{ }$ & $\sqrt{ }$ & $\sqrt{ }$ & - & - & - & - & {$[38]$} \\
\hline Packaging reduction & $\sqrt{ }$ & - & - & - & - & - & - & [39] \\
\hline Deposit fund & $\sqrt{ }$ & - & - & - & - & - & - & [26] \\
\hline Take back obligation & $\sqrt{ }$ & - & - & - & - & $\sqrt{ }$ & $\sqrt{ }$ & [9] \\
\hline Drop box facility & $\sqrt{ }$ & - & - & $\sqrt{ }$ & - & $\sqrt{ }$ & $\sqrt{ }$ & [5] \\
\hline Recycling technology creation & $\sqrt{ }$ & $\sqrt{ }$ & $\sqrt{ }$ & $\sqrt{ }$ & - & $\sqrt{ }$ & $\sqrt{ }$ & {$[16,26,38]$} \\
\hline Standard equipment utilization* & $\sqrt{ }$ & $\sqrt{ }$ & - & - & $\sqrt{ }$ & $\sqrt{ }$ & $\sqrt{ }$ & - \\
\hline Skill accreditation (employee competency) & $\sqrt{ }$ & $\sqrt{ }$ & - & $\sqrt{ }$ & $\sqrt{ }$ & $\sqrt{ }$ & $\sqrt{ }$ & {$[14]$} \\
\hline Quality of product (longevity of extension) & $\sqrt{ }$ & $\sqrt{ }$ & $\sqrt{ }$ & - & $\sqrt{ }$ & $\sqrt{ }$ & - & {$[26]$} \\
\hline Organizational commitment & $\sqrt{ }$ & $\sqrt{ }$ & - & - & - & $\sqrt{ }$ & - & {$[11,35]$} \\
\hline Budget allocation & $\sqrt{ }$ & $\sqrt{ }$ & - & $\sqrt{ }$ & $\sqrt{ }$ & $\sqrt{ }$ & $\sqrt{ }$ & {$[13]$} \\
\hline Inclusion of post-use product handling & $\sqrt{ }$ & - & $\sqrt{ }$ & - & - & - & - & [34] \\
\hline Technology conversion & $\sqrt{ }$ & $\sqrt{ }$ & - & $\sqrt{ }$ & $\sqrt{ }$ & $\sqrt{ }$ & $\sqrt{ }$ & {$[14,26]$} \\
\hline SMEs coaching* & - & $\sqrt{ }$ & $\sqrt{ }$ & $\sqrt{ }$ & $\sqrt{ }$ & - & $\sqrt{ }$ & - \\
\hline Enterprise alliances & - & $\sqrt{ }$ & - & - & $\sqrt{ }$ & - & - & {$[14,36,38]$} \\
\hline Inclusion of product content and duration* & $\sqrt{ }$ & - & - & $\sqrt{ }$ & - & - & - & - \\
\hline Corporate citizenship & - & - & - & - & - & - & - & [41] \\
\hline \multicolumn{9}{|l|}{ Public: } \\
\hline Public participation awareness & $\sqrt{ }$ & - & - & $\sqrt{ }$ & $\sqrt{ }$ & $\sqrt{ }$ & $\sqrt{ }$ & {$[14,9]$} \\
\hline Eco shopping decision & $\sqrt{ }$ & - & - & - & - & $\sqrt{ }$ & - & {$[20]$} \\
\hline Reduce replacement frequency & $\sqrt{ }$ & - & - & $\sqrt{ }$ & - & $\sqrt{ }$ & - & {$[16,26]$} \\
\hline Separate own e-waste & $\sqrt{ }$ & - & - & $\sqrt{ }$ & - & $\sqrt{ }$ & - & {$[40]$} \\
\hline Reasonable reimbursement (incentives) & $\sqrt{ }$ & - & - & - & - & $\sqrt{ }$ & - & {$[8,40]$} \\
\hline Willingness to pay recycling cost & & - & - & $\sqrt{ }$ & - & - & - & {$[40]$} \\
\hline Fairness in using electronic product* & $\sqrt{ }$ & - & - & - & - & $\sqrt{ }$ & - & - \\
\hline \multicolumn{9}{|l|}{ Government: } \\
\hline Illegal import restriction* & $\sqrt{ }$ & - & $\sqrt{ }$ & - & - & - & - & - \\
\hline Electronic product national standard arrangement* & - & $\sqrt{ }$ & $\sqrt{ }$ & - & $\sqrt{ }$ & - & - & - \\
\hline Collecting point extension & $\sqrt{ }$ & - & - & $\sqrt{ }$ & - & $\sqrt{ }$ & $\sqrt{ }$ & {$[26]$} \\
\hline Invention of handling mechanism & $\sqrt{ }$ & - & $\sqrt{ }$ & $\sqrt{ }$ & $\sqrt{ }$ & $\sqrt{ }$ & $\sqrt{ }$ & [37] \\
\hline Health and social awareness instillation & $\sqrt{ }$ & - & - & $\sqrt{ }$ & $\sqrt{ }$ & $\sqrt{ }$ & $\sqrt{ }$ & {$[6,14]$} \\
\hline Vocational education for human resource preparation* & - & - & - & $\sqrt{ }$ & - & - & - & - \\
\hline Storage point & $\sqrt{ }$ & - & - & $\sqrt{ }$ & - & $\sqrt{ }$ & - & {$[10,37]$} \\
\hline Professional management of secondary market & - & - & $\sqrt{ }$ & - & - & - & $\sqrt{ }$ & {$[26]$} \\
\hline Business localization* & - & - & - & - & - & $\sqrt{ }$ & - & - \\
\hline Tax arrangement (additional or reduction) $*$ & $\sqrt{ }$ & - & - & - & - & - & - & - \\
\hline Jobs creation & $\sqrt{ }$ & - & - & - & $\sqrt{ }$ & - & $\sqrt{ }$ & {$[37]$} \\
\hline Knowledge building and deployment & $\sqrt{ }$ & - & $\sqrt{ }$ & $\sqrt{ }$ & $\sqrt{ }$ & $\sqrt{ }$ & - & {$[20]$} \\
\hline Program of restructuration machine* & - & $\sqrt{ }$ & - & - & - & - & - & - \\
\hline Budget provision from $\mathrm{APBN}^{*}$ & $\sqrt{ }$ & $\sqrt{ }$ & - & $\sqrt{ }$ & - & $\sqrt{ }$ & $\sqrt{ }$ & - \\
\hline Regulation alignment between departments* & $\sqrt{ }$ & - & $\sqrt{ }$ & $\sqrt{ }$ & $\sqrt{ }$ & $\sqrt{ }$ & - & - \\
\hline New entrepreneur invention program & - & $\sqrt{ }$ & - & - & $\sqrt{ }$ & - & $\sqrt{ }$ & {$[14,36,38]$} \\
\hline Third party provision & $\sqrt{ }$ & $\sqrt{ }$ & - & - & - & $\sqrt{ }$ & - & {$[8,20,9,37,44]$} \\
\hline Social Punishment* & $\sqrt{ }$ & - & - & - & - & $\sqrt{ }$ & - & - \\
\hline Synergy of key actors & $\sqrt{ }$ & $\sqrt{ }$ & $\sqrt{ }$ & $\sqrt{ }$ & $\sqrt{ }$ & $\sqrt{ }$ & $\sqrt{ }$ & {$[34,37]$} \\
\hline Integrated implementation & $\sqrt{ }$ & $\sqrt{ }$ & - & $\sqrt{ }$ & $\sqrt{ }$ & $\sqrt{ }$ & $\sqrt{ }$ & {$[34,36]$} \\
\hline Control mechanism of RL implementation* & $\sqrt{ }$ & - & - & - & - & - & - & - \\
\hline Green industrial development & - & $\sqrt{ }$ & - & $\sqrt{ }$ & - & $\sqrt{ }$ & - & {$[36]$} \\
\hline SMEs-Industry link and match* & - & $\sqrt{ }$ & - & - & $\sqrt{ }$ & - & $\sqrt{ }$ & - \\
\hline Process modernization of SMEs* & - & - & - & - & $\sqrt{ }$ & - & $\sqrt{ }$ & - \\
\hline Tariff adjustment & - & - & - & - & - & - & - & {$[8,10]$} \\
\hline Waste to energy program & $\sqrt{ }$ & $\sqrt{ }$ & - & - & - & $\sqrt{ }$ & - & {$[8,10]$} \\
\hline Social and public facility utilization* & - & - & - & - & - & - & $\sqrt{ }$ & - \\
\hline Monopolistic collective systems & - & - & - & - & - & $\sqrt{ }$ & - & {$[42]$} \\
\hline \multicolumn{9}{|l|}{ All Stakeholders: } \\
\hline Environmental preservation & $\sqrt{ }$ & $\sqrt{ }$ & $\sqrt{ }$ & $\sqrt{ }$ & $\sqrt{ }$ & $\sqrt{ }$ & $\sqrt{ }$ & {$[3,6,8,10,26,34]$} \\
\hline Prestige consideration (image, reputation) & $\sqrt{ }$ & $\sqrt{ }$ & - & $\sqrt{ }$ & - & $\sqrt{ }$ & $\sqrt{ }$ & {$[6,14,36,41]$} \\
\hline
\end{tabular}


After sales service is needed to extend the life of electronic products. Usually, damaged electronic products are repaired for reuse. If those products cannot be used anymore, the owner will trade in with the new one in a secondary market. Unfortunately, usually retailers are only willing to buy these products at the lowest price, so that, the owners often cancel to sell it and prefer to keep it at home.

There are 7 actions recommended by government for community and only one action was not found in literature, i.e. fairness in using electronic product. Finally, this research found 28 actions that must be done by government itself. These phenomena give an impression that governments in many emerging countries have not paid great attention to SRL implementation, so they get the most responsibility than others.

Table 9: Linkage of reverse logistics and sustainability concept

\begin{tabular}{|c|c|c|c|c|}
\hline \multirow{2}{*}{ Sustainable Reverse Logistics Categories } & \multicolumn{4}{|c|}{ The Reasons to Conduct SRL } \\
\hline & Profit & People & Planet & Reputation \\
\hline Businesses: & & & & \\
\hline Eco-friendly product design & & $\sqrt{ }$ & $\sqrt{ }$ & $\sqrt{ }$ \\
\hline After sales service & & $\sqrt{ }$ & & $\sqrt{ }$ \\
\hline Packaging reduction & $\sqrt{ }$ & & $\sqrt{ }$ & $\sqrt{ }$ \\
\hline Deposit fund & $\sqrt{ }$ & & & \\
\hline Take back obligation & & & $\sqrt{ }$ & $\sqrt{ }$ \\
\hline Drop box facility & & $\sqrt{ }$ & $\sqrt{ }$ & \\
\hline Recycling technology creation & & & $\sqrt{ }$ & $\sqrt{ }$ \\
\hline Standard equipment utilization & & $\sqrt{ }$ & $\sqrt{ }$ & \\
\hline Skill accreditation (employee competency) & & $\sqrt{ }$ & & \\
\hline Quality of product (extension of longevity) & $\sqrt{ }$ & & & $\sqrt{ }$ \\
\hline Organizational commitment & & & & $\sqrt{ }$ \\
\hline Budget allocation & $\sqrt{ }$ & & & \\
\hline Inclusion of post-use product handling & & $\sqrt{ }$ & $\sqrt{ }$ & \\
\hline Technology conversion & & & $\sqrt{ }$ & $\sqrt{ }$ \\
\hline SMEs coaching & & $\sqrt{ }$ & & \\
\hline Enterprise alliances & $\sqrt{ }$ & & $\sqrt{ }$ & \\
\hline Inclusion of product content and duration & & $\sqrt{ }$ & & \\
\hline Corporate citizenship & & $\sqrt{ }$ & $\sqrt{ }$ & $\sqrt{ }$ \\
\hline Public: & & & & \\
\hline Public participation awareness & & & $\sqrt{ }$ & $\sqrt{ }$ \\
\hline Eco shopping decision & $\sqrt{ }$ & & $\sqrt{ }$ & $\sqrt{ }$ \\
\hline Reduce replacement frequency & & & $\sqrt{ }$ & $\sqrt{ }$ \\
\hline Separate own e-waste & & $\sqrt{ }$ & $\sqrt{ }$ & $\sqrt{ }$ \\
\hline Reasonable reimbursement (incentives) & $\sqrt{ }$ & & & \\
\hline Willingness to pay recycling cost & & & $\sqrt{ }$ & $\sqrt{ }$ \\
\hline Fairness in using electronic product & & & $\sqrt{ }$ & $\sqrt{ }$ \\
\hline Government: & & & & \\
\hline Illegal import restriction & & & $\sqrt{ }$ & \\
\hline Elect. prod. national stand. arrangement & & $\sqrt{ }$ & $\sqrt{ }$ & $\sqrt{ }$ \\
\hline Collecting point extension & & & $\sqrt{ }$ & \\
\hline Invention of handling mechanism & & & $\sqrt{ }$ & \\
\hline Health and social awareness instillation & & $\sqrt{ }$ & & \\
\hline Vocational education for HR preparation & & $\sqrt{ }$ & $\sqrt{ }$ & \\
\hline Storage point & & & $\sqrt{ }$ & \\
\hline Professional mgt. of secondary market & $\sqrt{ }$ & $\sqrt{ }$ & & \\
\hline Business localization & & $\sqrt{ }$ & $\sqrt{ }$ & \\
\hline Tax arrangement & $\sqrt{ }$ & & & \\
\hline Jobs creation & & $\sqrt{ }$ & & \\
\hline Knowledge building and deployment & & $\sqrt{ }$ & & \\
\hline Program of restructuration machine & & $\sqrt{ }$ & & \\
\hline Budget provision from APBN & $\sqrt{ }$ & & & \\
\hline Regulation alignment between departments & & & $\sqrt{ }$ & \\
\hline New entrepreneur invention program & & $\sqrt{ }$ & & $\sqrt{ }$ \\
\hline Third party provision & & & $\sqrt{ }$ & \\
\hline Social Punishment & & $\sqrt{ }$ & & \\
\hline Synergy of key actors & & $\sqrt{ }$ & $\sqrt{ }$ & \\
\hline Integrated implementation & & & $\sqrt{ }$ & $\sqrt{ }$ \\
\hline Control RL implementation & & & $\sqrt{ }$ & \\
\hline Green industrial development & & & $\sqrt{ }$ & $\sqrt{ }$ \\
\hline SMEs-Industry link and match & & $\sqrt{ }$ & $\sqrt{ }$ & \\
\hline Process modernization of SMEs & & $\sqrt{ }$ & $\sqrt{ }$ & \\
\hline Tariff adjustment & $\sqrt{ }$ & & & \\
\hline Waste to energy program & $\sqrt{ }$ & $\sqrt{ }$ & $\sqrt{ }$ & $\sqrt{ }$ \\
\hline Social and public facility utilization & & $\sqrt{ }$ & & \\
\hline Monopolistic collective systems & & $\sqrt{ }$ & $\sqrt{ }$ & $\sqrt{ }$ \\
\hline
\end{tabular}

To ensure that RL activities are very closely with sustainability concepts, each construct is grouped into four elements of sustainability depicted in Table 9. Interaction between $\mathrm{RL}$ categories and each element in sustainability concepts reflects the reasons why the stakeholders conduct SRL activities. However, government has never taken profit for government itself. The benefits gained from SRL activities are used for community welfare in form of circular economy.

Based on literature review and interview results, the duties of businesses suggested by government encompass creating ecofriendly electronic product design for easy features upgrading, providing after sales service to avoid quick replacement, reducing product package to save resources, initiating deposit fund to pay the environmental recovery, obligating take back program to provide collecting facilities, building drop box to facilitate community disposing used electronic product, finding recycling and e-waste conversion technology, utilizing standard equipment for maintaining society health, improving employee competency in e-waste processing. The business should strive to create an extension longevity of product, increase the organization commitment to implement RL especially in budget allocation, train the SMEs to process e-waste, publish how to handle product after using and product content, and overall, grow corporate citizenship. Government expects society to aware and participate in recycling program, by separating their own e-waste, ecoshopping, and reducing electronic product replacement. Government also hopes the public willing to pay cost of environmental recovery. Using electronic product fairly is an assertion that cannot be avoided. Although communities have also an obligation to protect the environment, they still expect to receive the reasonable reimbursement of their used electronic product unless they are reluctant to give their product.

The first government action to ensure SRL program will be implemented properly is restriction of illegal import used electronic products, since those products and their parts often cannot be utilized and only littering the environment. Moreover, informal businesses that seeks to profit from those products often ignoring safety and health process in reverse chain. Therefore, government should immediately make a regulation and national standard of import electronic product that will be sold in Indonesia and how to treat them, so they are not quickly pollute the environment.

This research finds some communities' expectations from a preliminary research, for example, collecting point facility to get a lot of amount of e-waste should be provided by government, because e-waste is a resource for SRL activities [4]. They should also easy to find a drop box by providing it close to the community. While based on businesses perspectives, government should motivate communities to give their used electronic product by giving a magnitude incentive. Regarding incentive for communities, the researcher suggests to government to make an incentive mechanism or regulation The Environment and Hygiene Office has a pick-up program for used electronic products, however, they do not give incentive to owners so they are often unmotivated to hand over those products for recycling. So that, instillation of health and social awareness in conducting SRL activities are also a big homework for government in emerging countries. 


\subsection{The Sound of Sustainable Reverse Logistics Theory building for Emerging Countries}

Building SRL theory particularly for emerging countries is not an easy problem. Government should start from providing a good infrastructure including technology, setting up human resource capacity including their awareness and knowledge maturity, formulating the regulation and policies, arranging the mechanism, and designing monopolistic collective system. If the process mechanism in reverse chain has been running, the next step is providing professional management of secondary market. According to the head of sub directorate of e-waste and recycle, for implementing SRL program, Indonesian Government must depart from making a policy. After that the policy should be socialized so community wants to participate. While communicating the program, government must immediately build the infrastructure, and the last step is program enforcement at all level of society, if needed, mechanism enforcing of punishment should be prepared. Integrated implementation and all stakeholder involvement are also needed to ensure that all RL activities are in line with quattro bottom line concept.

This research is categorizing the stakeholder into two groups, i.e. internal and external stakeholder. Internal stakeholder consists of consumer, manufacturer, and intermediary business. While, external stakeholder comprises of environment, society, and government itself. Government intervenes other stakeholders to support and conduct SRL program with regard to the principle of sustainability in order not to harm other interests (Figure 3).

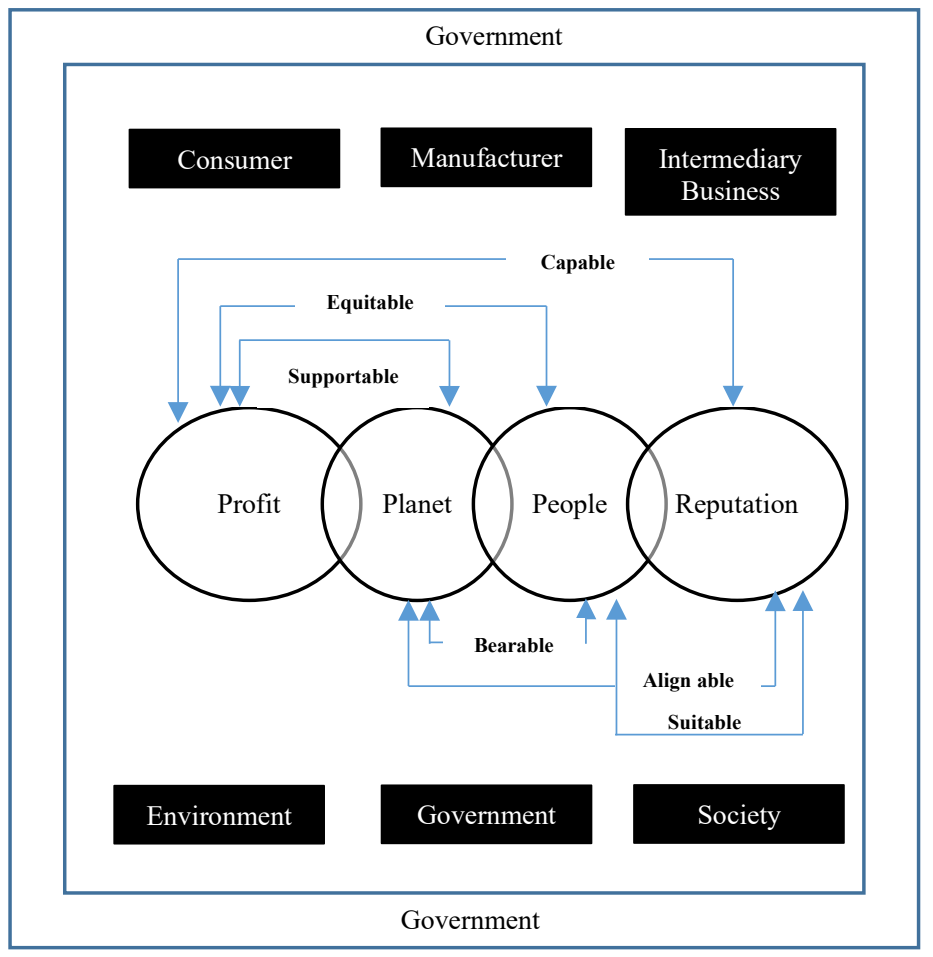

Figure 3: Quattro Bottom Line Approach for Sustainable Reverse Logistics Theory

The next step in building SRL theory is rearranging individual practices and literatures into "meta" constructs. In general literature review that had low levels of adoption, limited applicability and/or which did not relate to other practices were dropped so for further analysis we only use 51 constructs. The SRL theory to be built refers to two themes, namely activities related to RL implementation that must be conducted by all stakeholders based on government perspective and sustainability concepts with its four elements, i.e. profit, planet, people, and reputation (Figure 3). In building the SRL theory, the researcher seeks to balance between two interests. Therefore, this research formulates the sixth balancing constructs, namely: supportable, equitable, capable, bearable, align able, and suitable that will be described below,

- Supportable, re-design the way our economy works and rebuild a restorative economy through creativity and also innovation, generate business and economic opportunity (Profit) and provide environmental benefits through renewable and reusable resources as materials in an efficient way (Planet).

- Equitable, conformity between opportunities to create greater value and align incentives (Profit) and societal benefits through invention of job creation and additional income in reverse chain (People)

- Capable, ability to maximize resources in-use, maintain, repair, and upgrade the lifetime of electronic products will bring benefit (Profit) and demonstrate positive image (Reputation).

- Bearable, alignment of responsibility to maintain the environmental preservation (Planet) and global healthcare activity in reverse chain (People)

- Align able, fair phone design in using materials, good working conditions to enable the reuse and recycling of parts (Planet) will anchor deep niche position in the market (Reputation)

- Suitable, worthy activities in supporting the program to reach social welfare (People) and to be responsible in using electronic product and/or handling their own e-waste (Reputation).

Ideally a theory is built by adjusting why the theory is needed, where that theory will be applied, who the actor is, and what the outcome and expectation are. As explained in previous section, the SRL theory is needed for handling e-waste problem due to low of public awareness in using electronic product especially MP and almost of them do not know how to treat the used MP that is no longer used. Therefore, the SRL theory that will be applied in emerging countries, has to be made and initiated by government. The theory is designed to encourage other stakeholders conduct RL practices accordance with expected output and outcomes. After describing the constructs, either from literature or individual practice (Table 8 and 9) and exploring the possible interaction between sustainable constructs (Figure 3), this research categorizes these constructs to adopt parsimony and complete requirement in theory building. As explained in this research method section, this research uses three types of evaluations, namely criterion-focused evaluation, impact focus, and implementation focus. Table 10 is the end result of this analysis. Due to this theory building is built from government perspective, this research has to consider the overall vision, mission, function, and primary task of government. This research summarized those considerations into four categories, namely infrastructure and facilities provision, human resource commitment, regulation, and managerial orientation. 
Table 10: Rearranging literatures review and individual practices into meta constructs

\begin{tabular}{|c|c|c|}
\hline Meta Constructs & Literatures Review and Individual Practices & $\begin{array}{c}\text { Number of Governmen } \\
\text { Recommendation }\end{array}$ \\
\hline Infrastructures and & 1. Converting technology creation & 6 \\
\hline \multirow[t]{5}{*}{ Facilities } & 2. Government budget provision & 5 \\
\hline & 4. Collecting point extension & 4 \\
\hline & 5. Additional storage point & 3 \\
\hline & 6. Job creation & 3 \\
\hline & 7. Social and public facility utilization & 1 \\
\hline Human Resource & 1. Standard equipment utilization & 5 \\
\hline Commitments & 2. Health and social awareness instillation & 5 \\
\hline \multirow[t]{6}{*}{ (behavior and attitude) } & 3. Public participation awareness & 5 \\
\hline & 4. Reduce replacement frequency of electronic product & 3 \\
\hline & 5. Individual commitment & 3 \\
\hline & 6. Eco-shopping decision & 2 \\
\hline & 7. Willingness to pay recycling cost & 2 \\
\hline & 8. Fairness in using electronic products & 2 \\
\hline \multirow[t]{26}{*}{ Regulations } & 1. Synergy of key actors & 7 \\
\hline & 2. E-waste handling mechanism & 6 \\
\hline & 3. Integrated implementation & 6 \\
\hline & 4. Skill accreditation & 6 \\
\hline & 5. Regulation alignment between departments & 5 \\
\hline & 6. Building knowledge and deployment & 5 \\
\hline & 7. Coaching for SMEs & 5 \\
\hline & 8. Separate own e-waste & 3 \\
\hline & 9. Take back obligation & 3 \\
\hline & 10. Waste to energy program & 3 \\
\hline & 11. SMEs-Industry link and match & 3 \\
\hline & 12. Third party recycling business provision & 3 \\
\hline & 13. New entrepreneur invention program & 3 \\
\hline & 14. Enterprise alliance & 2 \\
\hline & 15. Inclusion of product content & 2 \\
\hline & 16. Inclusion of post-use product handling & 2 \\
\hline & 19. Social punishment & 2 \\
\hline & 20. Professional management of secondary market & 2 \\
\hline & 21. Preparation vocational education to increase individual capability & 1 \\
\hline & 22. Localization of reverse logistics business & 1 \\
\hline & 23. Tax arrangement both additional for new product or reduction for second hand product & 1 \\
\hline & 24. Program of restructuration machine & 1 \\
\hline & 25. Control mechanism of RL implementation & 1 \\
\hline & 26. Process of SMEs modernization & 1 \\
\hline & 27.Monopolistic collective system & 1 \\
\hline & 28. Deposit fund & 1 \\
\hline Managerial & 1. Budget allocation & 6 \\
\hline Orientation, Vision and & 2. Product quality & 5 \\
\hline \multirow[t]{5}{*}{ Mission } & 3. National standard arrangement particularly for electronic product & 3 \\
\hline & 4. Green industrial orientation & 3 \\
\hline & 5. After sales service & 3 \\
\hline & 6. Eco-friendly product design & 2 \\
\hline & 7. Packaging reduction & 1 \\
\hline
\end{tabular}

Category 1 - Infrastructure and Facilities. There are 7 selected constructs in this category. Converting technology creation is the most recommendation from government. It was recommended by 6 national agencies. if an emerging country has this technology, a lot of e-waste will not be a problem instead a resource. For providing it, government should prepare a large budget. Moreover, the budget is not only for technology procurement, but also to add drop box facilities, and extend the collecting and storage point.

Although Ministry of Environment and Forestry has the largest responsibility, however, RL cannot be implemented without supporting from all parties include from other departments. Two of departments did not have good alignment between the element of sustainability, especially between profit and other elements. Some efforts to reduce plastics usage will never work due to other departments (Ministry of Industry and Ministry of trade) encourage precisely to produce it for the reason gaining economics and industrial growth.

Actually, Indonesia has a regulation to ban importing waste and used electronic product from other countries, however, we often still found those products in many places such as Wakatobi, Batam, Surabaya, Pare-Pare, and even in the capital city of Indonesia, Jakarta. There is no control mechanism to prevent importing e-waste, integrated RL implementation for handling ewaste problems, and significant investment for building a big industry in reverse chain. 
Category 2 - Human Resource Commitment. This research finds 9 constructs in category of human resource commitment. This category describes communities' (people) attitude toward SRL program. Public awareness is the central issue in this category for conducting SRL program. We divided public awareness into three dimensions, namely 1) awareness to use basic standard equipment such as rubber gloves, masker, and so on include taking care of community health; 2) awareness to actively participate in recycling program such as separating their own e-waste and willing to pay the recycling cost; and 3) awareness to prevent the increasing amount of e-waste by reducing replacement frequency, eco-shopping, and fairness in using electronic products. That e-waste problem is a small matter that does not need to get priority attention, e-waste is invaluable product and not as energy resources, e-waste problem is not my backyard and other negative syndrome have to be eliminated from societies' mind. Not only societies that should be aware, but also businesses and government itself must be conscious and should be the first guard of environment protecting initiative. Environment and Hygiene Office Jakarta Province failed to put the drop box facilities in each Transjakarta bus stop until now for a reason they do not know. Commitment to successfully implementing activities in reverse chain were evidenced in seventh ways [28], i.e.: 1) credibility of decision maker, in this case is government; 2) implementation mechanism include incentive to market; 3 ) significant attention of secondary market; 4) societies involvement; 5) sustainable commitment to high quality of operation facilities for managing e-waste; 6) Effectiveness evaluation to the strategy chosen; and 7) the clear legal protection for handling e-waste by government.

Category 3 - Regulation. This research found a lot of government responsibilities to regulate SRL program. The researcher believes these regulations (categories) will be the measurement of government performance in SRL implementation.

In the first type evaluation, this research found five evaluation criteria of SRL implementation. The evaluation criteria are classified into five dimensions, namely integrated enforcement of SRL program by all parties even among government agencies, obligation compliance to support SRL implementation, competency improvement to prevent SRL activities polluting the environment, creative ideas development to create income in reverse chain, and professional management to arrange SRL implementation properly.

This research establishes synergy of key actors such as government, businesses, and community; integrated SRL implementation; regulation alignment between department; and enterprise alliances as government responsibilities in integration enforcement of SRL program. While, obligation compliance dimension has seven indicators, namely willingness to separate ewaste by sorting the valuable material, conduct take back scheme, publish product content and post-use product handling in packaging, arrange reasonable reimbursement system, prevent illegal import of used electronic products, and socialize restructuration machine program to everyone that needs recycling machine but does not have enough money to buy it. Improvement of human resource competency is very important for implementing SRL, because to process used electronic product required a specific skill. Therefore, government responsible to increase return handling capability by giving a training and an accreditation certificate for individual or firm that really has recycling ability. Big companies are usually obliged to train small medium enterprises to transfer their skill in recycling process. Many developed countries such as Sweden and Japan provide vocational education specifically for increasing the skill in reverse chain, so they can operate the RL activities without damaging the environment and community interests.

The government responsibilities in creative idea development criteria comprise five indicators, namely building waste to energy (WTE) program, providing third party recycling business, inventing new entrepreneur in reverse chain field, organizing monopolistic collective system, and constructing deposit fund scheme. Many emerging countries have not been able to take benefit from e-waste, whereas developed countries import a lot of e-waste from their neighboring countries to be converted into energy. WTE needs a lot of resources, so the government in developed countries organizes monopolistic collective system to avoid informal group intervention. Nevertheless, Indonesian government is always trying to find new entrepreneurs in reverse chain field, due to many people in emerging countries make this activity as their primary livelihood. For businesses that have not been able to recycle their used product or to neutralize their hazardous products, government should provide third party recycling business. Since converting used electronic product into energy or other valuable products needs a lot of funds, constructing deposit fund scheme is urgent to do immediately.

The last regulation for SRL implementation is professional management that has the most number of indicators, i.e. professional in e-waste handling mechanism to avoid too large intervention of informal group, SMEs-industry link and match to improve employees' skill, social punishment application for tight SRL implementation in avoiding environmental pollution, secondary market management to develop business in reverse chain, business localization in reverse chain for easy controlling the SRL activities, SMEs modernization, and tax arrangement to grow the business spirit.

Category 4 - Managerial Orientation. In the forth category, this research found seven dimensions. The first government duty is providing budget for the expensive technology, facilities, and infrastructures and guarantee the quality of import electronic products that will be sold in Indonesia to prevent those products littering the environment quickly. Today, Indonesian government does not have a national standard for electronic products, so there are many unqualified products sold in Indonesian market. Besides easily damaged, these products are harmful to human body since they contain toxic and hazardous materials.

In managerial orientation, vision, and mission, government also should think about how to manage SRL activities from collecting process until selling the products to secondary market by using environmental friendly ways through reducing the use of packaging and trying to create eco-friendly products. Besides that, after sales service believed can reduce e-waste generation since this action adds life span of the products. Actually, all government agencies (respondents) recognize that environmental preservation is their responsibility. They are conscious that to protect the environment they should cooperate with others [2]. 


\section{PLANET}

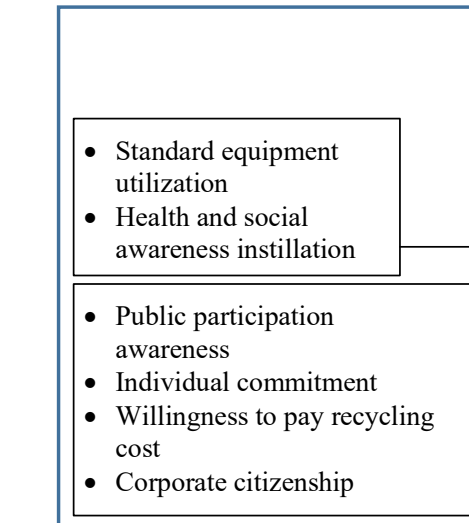

- Reduce replacement frequency

- Eco-shopping decision

- Fairness in using electronic products
- Converting technology creation

- Government budget provision

- Drop box facilities

- Collecting point extension

- Additional storage point

- Job creation

- Social and public facility utilization

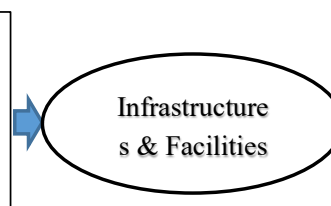
health

- Awareness to active participation

- Awareness to prevent the increasing amount of e-waste

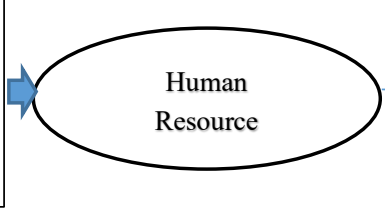

- Synergy of key actors

- Integrated implementation

- Regulation alignment

- Enterprise alliance

- Separate e-waste

- Take back scheme

- Product content

- Post-use product handling

- Reasonable reimbursement

- Restriction of illegal import

- Restructuration Machine

- Return handling capability

- Accreditation certificate

- SMEs coaching

- Vocational education

- Waste to energy program

- Third parties RL business

- New entrepreneur invention

- Monopolistic collecting system

- Deposit funds

- E-waste handling mechanism

- SMEs-Industry link and match

- Social punishment

- Secondary market

management

- Business localization

- Tax arrangement

- Budget allocation

- Product quality

- Green industrial orientation

- National standard of electronic product

- After sales service

- Eco-friendly product design

- Packaging reduction

\section{PEOPLE}

Figure 4: A model of sustainable reverse logistics for emerging countries from government perspectives 
They know also that community in emerging countries usually have low awareness to protect the environment, therefore, the initiative must come from the government. Unfortunately, in many emerging countries, the government itself has often not felt that activity in reverse chain currently is very important due to the abundant of production in forward chain. Some respondents, especially Ministry of Environment and Forestry and Environment and Hygiene Office plans to apply punishment to arouse community awareness. They believe that must use the hard way. Besides that, they have to think how to implement and control that regulation.

After finding the evaluation criteria, this research uses impact evaluation for describing the direct and indirect impact of the use of indicators, dimensions, and variables formatted to measure the successful of SRL theory implementation, that is a reverse logistics theory that constantly in line with four elements in sustainability concepts, i.e. profit, planet, people, and reputation. SRL theory is recommended if activities in reverse chain will be applied in emerging countries. Using reverse logistics terminology is perceived to be no longer appropriate since many people ignore environmental friendly way. Therefore, sustainable reverse logistics concept is a theory which should be standardized for emerging countries.

Figure 4 is the last figure and the end of finding in this research that summarize all constructs for building SRL theory from government perspectives. Quattro bottom line as an approach that can preserve RL activities will not interfere other interests and the sixth ability to keep the balancing among interests and stakeholders will consider to be used in this research.

This research uses implementing-focused evaluation in the last step to test the theory building. For this type of evaluation, this research has two main propositions and eighteen proponent propositions to build a whole theory of sustainability reverse logistics and explain each interaction between two spheres, i.e.: capable, equitable, align able, supportable, suitable and bearable. However, this research does not examine the theory, but only formulate the propositions.

Proposition 1: The infrastructures and facilities provision, human resource commitment, regulation establishment, and managerial orientation are required to build a sustainable reverse logistics.

Proposition 1a: Converting technology creation, budget provision by government, providing drop box facilities, collecting point extension, additional storage point, job creation, and social and public facility utilization are needed for infrastructures and facilities provision.

Proposition 1b: Awareness to individual health, active participation, and prevent the increasing amount of e-waste are needed to build human resource commitment.

Proposition 1b1: Utilization of standard equipment and instillation of health and social awareness are needed to build individual health awareness

Proposition 1b2: Public participation, individual commitment, willingness to pay recycling cost, and corporate citizenship are believed can build awareness to active participation.
Proposition 1b3: Reduce replacement frequency, eco-shopping decision, and fairness in using electronic product are needed to prevent the increasing amount of e-waste.

Proposition 1c: Integrated enforcement, obligation compliance, competency improvement, creative idea development, and professional management should be regulated immediately.

Proposition 1c1: Synergy of key actors, integrated implementation, alignment of regulation, and enterprise alliance are needed to integrate the implementation.

Proposition 1c2: Separating own e-waste, taking back scheme, inclusion of product content and post-use product handling, reasonable reimbursement, restriction of illegal import, and restructuration machine are the form of obligation compliance.

Proposition 1c3: Return handling capability, accreditation certificate, SMEs coaching, and vocational education are needed to improve the competency.

Preposition 1c4: Waste to energy program, third parties recycling business, new entrepreneur invention, monopolistic collecting system, and deposit funs are the creative ideas that should be regulated immediately.

Preposition 1c5: E-waste handling mechanism, link and match between industry and SME's, social punishment, management of secondary market, business localization, tax arrangement, and modernization of SMEs need professional management.

Preposition 1d: Budget allocation, product quality, green industry, national standard for electronic products, after sales service, ecofriendly product design, reduce packaging are the types of managerial orientation.

Preposition 2: Sustainable reverse logistics could be realized by referring quattro bottom line conceptual framework.

Proposition 2a (capable): Stakeholders capability to balance target profit achievement and reputation recognition is required to create sustainable reverse logistics.

Proposition 2b (equitable): Stakeholders fairness between obtaining profit and preserving social harmony is required to realize sustainable reverse logistics.

Proposition 2c (align able): Align able of Stakeholders interest between to reach reputation recognition and environmental conservation is required to establish sustainable reverse logistics.

Proposition $2 \mathrm{~d}$ (bearable): Stakeholders responsibility to preserve social harmony and environmental conservation is required to create sustainable reverse logistics.

Preposition 2e (suitable): worthy activities in supporting the program to reach social welfare and to be responsible in using and producing electronic product and/or handling their own e-waste are the suitable components to format sustainable reverse logistics

Preposition $2 \mathrm{f}$ (supportable): re-design the way our economy works and re-build a restorative economy through creativity and also innovation, generate business and economic opportunity and provide environmental benefits through renewable and reusable resources as materials in an efficient way. 


\section{Conclusion and Further Research}

This research uses criteria of good theory [29, 32] to break down few conclusions. First, this research highlights 51 selected constructs for building sustainable reverse logistics theory that categorized into 4 dimensions to fulfil parsimony requirement and evaluation criteria in building a theory. They are infrastructures and facilities provision, human resource commitment, regulation, and managerial orientation. Second, the causality relationship of major constructs both direct and indirect impact of SRL implementation, is used to explain the internal consistency and impact criteria. Third, the implementation criteria are met by finding the stakeholders obligations to realize SRL program. There is a small chance for community or businesses in emerging countries to initiate conduct SRL activities, therefore these constructs are the obligations for them. In the case of Malaysia, manufacturers are not proactive in taking advantage of product take back since they regard it as service cost $[36,46]$. While in Thailand, they still face many problems in conducting RL such as return policy, procedure management, transportation and communication [6]. The author believes that many poor and emerging countries still grapple with the same problem. Fourth, in term of fulfilling generalization criterion, it is better to test in some emerging countries with the same phenomena before using this theory. For further research, it is needed to explore the new constructs based on businesses and communities' inspirations. Furthermore, for managerial implication, government will adopt those constructs to measure SRL performance.

\section{Conflict of Interest}

The authors declare no conflict of interest.

\section{Acknowledgment}

This study would not have been possible without support material and non-material from LPDP scholarship from The Ministry of Finance and The Ministry of Research Technology and Higher Education. The author would like to thank and appreciate the invaluable constructive views and comments by reviewers.

\section{References}

[1] H. Maheswari, G. Yudoko, A. Adhiutama, "Towards sustainable reverse logistics: A conceptual framework of quattro bottom line approach" in Indstr. Eng. and Eng. Mgt Confr. 2017, 1377-1381,

[2] G. Yudoko, "Integrated municipal solid waste planning and management (IMSWPM) in developing countries: A conceptual framework", J. Mgt. Tech., 2007

[3] Organization for Economic Cooperation and Development (OECD), "OECD economic survey: Indonesia", OECD Publishing, 2010

[4] H. Maheswari, G. Yudoko, A. Adhiutama, "Stakeholder engagement model in quattro helix model for mobile phone reverse logistics in Indonesia: A conceptual framework" in IOP Conf. Series: Mat. Sci. and Eng., 2017. https://doi:10.1088/1757-899X/277/1/012062

[5] P. Andarani, N. Goto, "Potential e-waste generated from households in Indonesia using material flow analysis" J Mater Cyc. Waste Mgt., 16, 306320, 2014. http://doi.org/10/1007/s10163-013-0191-0

[6] P. Tanskanen, Electronics waste: recycling of mobile phones, INTECH Open Access Publisher, 2012

[7] J.D. Demajorovic, E.E.F. Augusto, M.T.S. De Souza, "Reverse logistics of ewaste in developing countries: challenges and prospects for the Brazilian model", Ambt. And Soc, 19 (2), 117-136, 2016
[8] P.R. Kleindofer, K. Singhal, L.N.V Wassenhove, "Sustainable operations management” Prod. and Oprt. Mgt., 14 (4), 482-492, 2005. ABI/INFORM Global

[9] P.J. Daugherty, A.E. Ellinger, "Reverse Logistics: The relationship between resorce commitment and program performance", J. of Busn. Logst., 22 (1), $107-123,2001$

[10] L. Paquette, "Reverse logistics and the creations of reverse flows for the mobile phone industry" Thesis, Aarush University, 2009

[11] D.S. Rogers, P. Tibben-Lembke, "Going Backwards: Reverse Logistics Trends and Practices", Reverse Logistics Executive Council, University of Nevada, Reno Center for Logistics Management, 1998

[12] H.C. Pfohl, A. Bode, H.T.V. Nguyen, "Adaptability to reverse logistics - An empirical study in European electronics industry", Journal of Glob. Strat. Mgt., 6 (1), 89-102, 2012. http://doi.org/10.20460/JGSM.2012615789.

[13] I. El-Nakib, "Reverse logistics: A comparison of electronic waste recycling between Switzerland and Egypt" in Global Conference on Operations and Supply Chain Management, 2012, ISBN No. 978-967-5705-06-9

[14] M.D. Abdulrahman, N. Subramanian, "Barriers in implementing reverse logistics in Chines Manufacturing Sectors: An Empirical Analysis" in the $23^{\text {rd }}$ Annual POMS Conference, 2012

[15] A. Agrawal, "Reverse logistics: Performance measure and their effect in product lifecycle" in Inter. Jour. of Core Eng. and Mgt, 1 (2) 14-23, 2014, ISSN: 23489510

[16] S. Emmet, V. Sood, Green Supply Chain, A John Wiley and Sons, Ltd. Publication, United Kingdom, 2010

[17] E. Damanhudi, "The role of informal collector of recyclable waste and used goods in Indonesia", Post-Cons. Waste Rec. and Opt. Prod., Intechopen.com, 2012, Croatia

[18] R.F. dos Santos, F.A.S. Marins, "Integrated model for reverse logistics management of electronic products and components" Procedia Computer Science, 55, 575-585, 2015

[19] M. Thierry, M.J.V.N. Salomon, J.V. Nunen, L.V. Wassenhove, "Strategic issue in product recovery management", California Mgt. Rev., 37 (2), 114 135, 1995, http://doi.org/10.2307/41165792

[20] M.P. De Brito, R. Dekker, "A framework for reverse logistics", ERIM Rep. Series, 1-23, 2003, http://doi.org/10.1007/978-3-540-24803-3 1

[21] S.S. Khan, S.A. Lodhi, F. Akhtar, "Sustainable WEEE management solution for developing countries applying human activity system modeling", Mgt. of Envr. Qual., 26 (1), 84-101, 2014, http://doi.org/10.1108/MEQ-05-2014-0072

[22] V.P. Rindova, I.O. Williamson, A.P. Petkova, J.M. Sever, "Being good or being known: An empirical examination of the dimensions, antecedents, and consequences of organization reputation", The Acadm. Of Mgt Journ, 48 (6), 1033-1049

[23] C.E. Carroll, "Corporate Reputation and the News Media in the United States" New York, NY: Routledge, 2011

[24] T. Passow, R. Fehlmann, H. Grahlow, "Country reputation - from measurement to management: The case of Liechtenstein, Corport. Rept. Rev, 7 (4), 309-326, 2005, http://doi.org/10.1057/palgrave.crr.1540229

[25] A. McKinnon, The role of government in promoting green logistics", The Chart. Inst. of Log. and Transp., 342-360, ISBN 97807494567888, 2010, United State.

[26] J. Aitken, A. Harrison, "Supply governance structures for reverse logistics systems", Intr. J of prt. and Prod. Mgt., 33 (6), 745-764, 2012, DOI: 10.1108/IJOPM-10-2011-0362

[27] W. Wilhelm, A. Yankov, P. Magee, "Mobile phone consumption behavior and the need for sustainability innovation", J. of Strt. Innvt. and Sust., 7 [2] 20-38, 2011

[28] M.A.P. Sari and Rustan, Implementation of good governance in waste management", PKP2A III LAN Samarinda (2013)

[29] R. Swanson, T.J. Chermack, Theory Building in Applied Disciplines", Berrett-Koehler Publ., 2013, San Fransisco

[30] D.K. Beckley, W.B. Logan, "The Retail Sales Person at Work", Gregg Publs., New York, NY, 1948

[31] M.Q. Patton, "Utilization-Focused Evaluation: The New Century Text", Sage Publicatio, UK, 1997

[32] J.G. Wacker, "A definition of theory: Research guidelines for different theory building research method in operation management", J. Opr. Mgt., 16, 361385,1998

[33] M. Bernon, J. Cullen, "An integrated approach to managing reverse logistics", Intrn. J. of Log. Resrc. and Applc., 10, 41-56, 2007

[34] C.H. Chiou, "Dynamic capabilities, collaborative network and business model: An empirical analysis of Taiwan HTC corporation", Affrican J. of Busn. Mgt. 5 (2), 299-305, 2011 
[35] H.L Correa, L.H. Xavier, "Concepts, design, and implementation of reverse logistics systems for sustainability supply chain in Brazil", J. of Oprt. And Supp. Cha. Mgt., 6 (1), 1-25, 2013

[36] S.M. Budijati, Model of Reverse Logistics Management: Close Loop and Opened Loop as well as Consumer Behavior Accommodation, Dissertation, UGM, 2016

[37] J-B. Sheu, "Green supply chain collaboration for fashionable consumer electronics products under third-party power intervention-a resources dependence perspective" Sustainability, 6, 2832-2875, 2014. http://doi.org/10.3390/su6052832

[38] R.G. de Sauza, J.C.N. Climaco, A.P. Sant'Anna, T.B. Rocha, R.A.B. Valle, O.L.G. Quelhas, "Sustainability assessment and prioritization of e-waste management", Wst. Mgt., 57, 46-56, 2016, http://dx.doi.org/10.1016/j.wasman.2016.01.034

[39] I. Vlachos, "A conceptual framework of reverse logistics impact on firm performance", Brit. Acdm. of Mgt (BAM) Confr., 2014
[40] P. Rajagopal, V.P.K. Sundram, B.M. Naidu, "Future direction of reverse logistics in gaining competitive advantage: A review literature", Int. J Sup. Chain. Mgt, 4 (1), 39-48, 2015

[41] J. Yin, Y. Gao, H. Xu, "Survey and analysis of consumers' behavior of waste mobile phone recycling in China", J of Clean. Prod., 1-9, 2013, http://dx.doi.org/10.1016/j.jclepro.2013.10.006

[42] R. Pinna, P.P. Carrus, "Reverse logistics and the role of fourth party logistics provider", Pathw. to Sup. Ch. Exc., www.intechopen.com

[43] A. Atasu, L.V.N. Wassenhove, "An operation perspective on product takeback legislation for e-waste: Theory, practice, and research need", Prod and Opr. Mgt., 21, (3), 407-422, 2012, ABI/INFORM Research

[44] H. Maheswari, "Supply Chain Management", Cent. Of Teach. Mat. Dev., Economic Faculty, Mercu Buana University, 2008.

[45] K.S. Khor, Z.M. Udin, "Impact of reverse logistics product disposition towards business performance in Malaysian E\&E companies", J. of Sup. Ch. And Cust. Rel. Mgt., 19 pg., 2012, DOI: 10.5171/2012.69946 


\section{Appendix}

\section{Constructs}

Eco-friendly product design

After sales service

Packaging reduction

Deposit fund

Take back obligation

Drop box facility

Recycling technology creation

Standard equipment utilization

Skill accreditation (employee competency)

Quality of product (longevity of extension)

Organizational commitment

Budget allocation

Inclusion of post-use product handling

Technology conversion

SMEs coaching

Enterprise alliances

Inclusion of product content and duration

Corporate citizenship

Public participation awareness

Eco shopping decision

Reduce replacement frequency

Separate own e-waste

Reasonable reimbursement (incentives)

Willingness to pay

Fairness in using electronic product

Illegal import restriction

Electronic product national standard arrangement

Collecting point extension

Invention of handling mechanism

Health and social awareness instillation

Vocational education for HR preparation

Storage point

Professional mgt. of secondary market

Business localization

Tax arrangement

Jobs creation

Knowledge building and deployment

Program of restructuration machine

Budget provision from APBN

Rules alignment

New entrepreneur invention program

Third party provision

Social Punishment

Synergy of key actors

Integrated implementation

Control RL implementation

Green industrial development

SMEs-Industry link and match

Process modernization of SMEs

Tariff adjustment

Waste to energy program

Social and public facility utilization

Monopolistic collective systems

\section{Definition}

Designing an electronic product that using eco-friendly resources and easy to upgrade the feature

Giving service after selling electronic product

Reducing the use of packaging by alternating usage

Providing budget by collecting from community for normalizing environmental condition

Designing return electronic product mechanism from point of consumption (consumer) to point of origin (producer)

Providing drop box to facilitate community bring and collect used electronic product

Creating a technology to recycle used electronic product

Enforcing employee to use standard equipment when conducting RL activities

Accrediting the employee to standardize competency of employee

Establishing the quality of product by adding longevity of extension

Preparing commitment of organization to conduct RL activities

Allocating budget to convert e-waste to be a valuable product

Publishing how to handle after using electronic product

Inventing a technology to convert e-waste to energy

Coaching small medium enterprise to recycle safely used electronic product

Alliancing enterprises for easy sharing the knowledge and facility

Writing electronic product content and duration in guidance book for informing the when they allow to replace it

A set of values or principles that drive an organization to become responsible engaged with particular RL activities [36]

Warning community to be aware to participate in RL program

Buying electronic product when it is needed

Reducing the frequency of electronic product replacement

Separating communities' own e-waste from household waste so that easy to recycle

Giving reasonable incentive to motivate owner of used electronic product to bring it for recycling

Influencing community want to pay e-waste converting cost

Using electronic product with reasonable way

Preventing import of electronic product illegally

Making national standard for electronic product

Adding collecting point for electronic products in many place

Inventing mechanism of e-waste handling for each stakeholder

Bringing strong understanding of health and social awareness

Developing vocational education to teach safety recycling technology

Building storage point to relocate used electronic products from drop box

Managing secondary market professionally to facilitate circulation of used electronic product

Placing businesses in reverse chain on particular area

Arranging tax reduction for reselling used electronic products

Creating a new job in reverse chain to help uneducated people as part of recycling program e.g. as scavenger.

Building knowledge to community about waste, hazardous and toxic materials

Subsidizing businesses by giving a new machine that is needed for converting e-waste to energy

Providing budget to run RL program

Aligning rules and regulation in each department for integrating RL program

Inventing new entrepreneurs that do business in recycling used electronic product

Providing a company that certified by government to conduct RL activity for firms that do not have recycling technology

Giving punishment to communities that avoid to separate their own e-waste from other kinds of waste, wasteful in using electronic product

Integrating key actors to implement $\mathrm{RL}$ activities together

Integrating RL activities to reduce e-waste faster

Controlling implementation of RL program to ensure not damaging the environment

Developing green industrial by making a competition

Creating link and match between SMEs and industry

Improving process modernization of SMEs in managing business in reverse chain

Adjusting tariff for electronic products that have longer life time

Implementing waste to energy program

Using social and public facility to facilitate business in reverse chain

Dominating collective system of used electronic product to avoid uncertain timing and quantity of returns 